\title{
Cyclin-Dependent Kinase Inhibitor 1B
}

National Cancer Institute

\section{Source}

National Cancer Institute. Cyclin-Dependent Kinase Inhibitor 1B. NCI Thesaurus. Code C17901.

Cyclin-dependent kinase inhibitor 1B (198 aa, $22 \mathrm{kDa}$ ) is encoded by the human CDKN1B gene. This protein plays a role in cell cycle arrest. 